\title{
Cognitive interventions to improve memory in healthy older adults: the use of Canadian (MEMO) and Brazilian (Stimullus) approaches
}

Isabelle Patriciá Freitas Soares Chariglione. Universidade Católica de Brasília Gerson Américo Janczura. Universidade de Brasília

Sylvie Belleville. Université de Montreal

\begin{abstract}
This study aimed to investigate the effects of a memory training (MEMO) and a memory stimulation (Stimullus) procedure in older adults with normal cognitive aging. The study was conducted with 44 participants of both sexes, healthy and over 60 years old, using a randomized control trial design with two groups receiving cognitive interventions and one control group with no intervention, with pre and post-intervention assessments. Results indicated that MEMO interventions produce more cognitive gains than the Stimullus intervention procedure. Visual memory and Face-Name Association tests presented significant differences between groups, but Free Recall and Image Recognition tests were insensitive to the interventions.
\end{abstract}

Keywords: older adults; memory; cognitive intervention; cognitive stimulation; cognitive training.

\section{Resumo}

Intervenções cognitivas no aprimoramento da memória em idosos saudáveis: o uso de metodologias canadense (MEMO) e brasileira (Stimullus). Este estudo investigou os efeitos de um treino de memória (MEMO) e de uma estimulação da memória (Stimullus) em idosos com envelhecimento cognitivo normal. 0 estudo foi realizado com 44 participantes de ambos os sexos, saudáveis e com mais de 60 anos de idade. Aplicou-se um delineamento controlado randomizado com dois grupos que receberam intervenções cognitivas e um grupo controle sem intervenção, com avaliações pré e pós-intervenção. Os resultados demonstraram que a intervenção do tipo MEMO produziu mais ganhos cognitivos do que Stimullus. O teste de memória visual e o teste de associação nome-rosto apresentaram diferenças significativas entre os grupos, mas os testes de recuperação livre de palavras e reconhecimento de imagens não foram sensíveis às intervenções.

Palavras-chave: idosos; memória; intervenção cognitiva; estimulação cognitiva; treino cognitivo.

\section{Resumen}

Intervenciones cognitivas para mejorar la memoria en ancianos saludables: el uso de metodologías canadiense (MEMO) y brasileña (Stimullus). Este estudio investigó los efectos de un entrenamiento de la memoria (MEMO) y una estimulación de la memoria (Stimullus) en pacientes de edad avanzada con el envejecimiento cognitivo normal. El estudio se realizó con 44 participantes de ambos sexos, saludables y con más de 60 años. Se aplicó un diseño aleatorizado controlado con dos grupos que recibieron las intervenciones cognitivas y un grupo de control sin intervención, con las evaluaciones previas y posteriores a la intervención. Los resultados mostraron que la intervención del tipo MEMO produjo más beneficios cognitivas que Stimullus. La prueba de memoria y asociación rostro-nombre visual mostró diferencias significativas entre los grupos, pero las pruebas de recuperación de palabras e reconocimiento de imágenes no fueron sensibles a las intervenciones.

Palabras clave: personas de edad avanzada; memoria; intervención cognitiva; estimulación cognitiva; entrenamiento cognitivo. 
Many studies with older healthy adults have shown that some interventions programs had improves cognitive performance in the domain trained. Evidence regarding prevention or delay of cognitive decline is insufficient with different types of interventions (Butler et al., 2018). It is difficult to define cognitive aging given that cognitive functions in this stage of development suffer gradual declines, which can be considered either normal or pathological (Netto, 2010). Several studies (eg, Belleville, 2008; Belleville et al., 2011; Belleville et al., 2006; Belleville et al., 2018; Chariglione \& Janczura, 2013; Gross, Rebok, Unverzagt, \& Brandt, 2011; Santos \& FloresMendoza, 2017) revealed both cognitive and neurobiological benefits in older adults that participated in intervention programs. It has been found that healthy older adults or those with mild cognitive impairment or dementia can benefit from at least one of the following cognitive intervention techniques: stimulation, training or rehabilitation (Bahar-Fuchs, Clare, \& Woods, 2013; Belleville, 2008; Clare et al., 2003; Mowszowski, Batchelor, \& Naismith, 2010).

Cognitive stimulation refers to non-specific interventions that are meant to improve well-being or general cognition. Cognitive training refers to a range of programs designed to improve the performance of a task and / or cognitive function by teaching strategies that the elderly can then use in their daily activities (Belleville, 2008; Belleville et al., 2018; Clare et al., 2000; Clare et al., 2003; Mowszowski et al., 2010). In turn, cognitive rehabilitation targets an individual's difficulty with a specific activity of their daily lives, for instance learning the name of their new caregiver, and is provided individually rather than in groups (Clare et al., 2009).

The traditional image of older adults as individuals dependent and isolated from the world has been replaced by the concept of "active aging", which seeks to deconstruct paradigms imposed by traditional and cultural customs of Brazilian society. The World Health Organization defines active aging as the optimization of health opportunities, participation and security to improve the quality of life as adults get older, with an individual, collective and universal challenge. In addition to participating in the labour market, the concept includes physical capacity and the involvement of older people in social, economic, cultural, spiritual and civil issues (Fernandes, 2014).

Although the senior citizens currently represent $10.8 \%$ of the population of Brazil (about 20.6 million people), it has been estimated that this number will grow until 2042 and gradually decrease by 2060 . Some studies suggest that life expectancy will be of 80 years in 2041 , reaching 81.2 years in 2060, corresponding to 58.4 million people (26.7\% of the total population) (Instituto Brasileiro de Geografia e Estatística [IBGE], 2014).

Significant cognitive changes can be also observed in the aging process, such as slowing cognitive processing, reduced attention span, and decrease in working, prospective and episodic memory (Moraes, Moraes, \& Lima, 2010; Naveh-Benjamin, \& Mayr, 2018; Xavier, 2006; Yassuda \& Paulo, 2010). Studying cognition is of interest to many researchers seeking to understand the declines, gain or maintenance of cognitive functions. Studies that have investigated the mechanisms underlying cognitive changes that occur during aging can be also contribute to define criteria that distinguish normal and pathological aging.

One of the most important changes for adaptation in healthy aging is the ability of individuals to memorize information. Changes in this ability affect the psychological and social well-being, which are necessary for the individual to feel and indeed take part in society. Generally, cognitive concerns in older adults start with complaints regarding the difficulty of memorizing daily experiences. In older ages difficulties are observed in the ability to evoke memories, which can be explained by a lack of access to records and not permanent oblivion. There are also observed difficulties in the formation of short-term memories (Gagnon \& Belleville, 2012; Matos \& Paixão Júnior, 2010).

It is well established in the literature that during the aging process there is a decline of some cognitive functions. This has encouraged researchers to study ways to improve cognitive functions and increase cognitive reserve, that is the ability to resist against the detrimental effect of brain changes on cognition. Several cognitive intervention techniques such as cognitive stimulation, cognitive training and cognitive rehabilitation, have been applied to promote this enhancement. Despite often being considered as equivalent these procedures differ in methodology (Mowszowski et al., 2010).

This paper reports the results of two memory intervention techniques - cognitive stimulation (Stimullus) and cognitive training (MEMO) - following the classification of Clare et al. (2003) reintroduced by Belleville (2008) and discussed by Mowszowski et al. (2010). The two types of procedures differ as to objectives and applicability.

Cognitive stimulation is aimed at functional improvement in daily life through repetition of certain activities. In turn, cognitive training targets the 
improvement of performance on a task and/or cognitive function through teaching strategies that the older adults can use in their daily activities (Bellander et al., 2016; Belleville, 2008; Clare et al., 2000; Clare et al., 2003; Mowszowski et al., 2010).

The intervention technique as cognitive stimulation consists on an improvement of the technique performed by Chariglione and Janczura (2013), which contributed to the research on the effects of different cognitive interventions on memory performance and neuropsychological measures in institutionalized older adults, relating to their education and the proposed interventions.

The intervention technique used as cognitive training represents an adaptation and translation of MEMO. It includes different ways to improve the memory of elders that present or not a cognitive impairment, which can be considered efficient, practical and capable of producing significant changes at the cerebral level, given that these seniors remain with high brain plasticity (Belleville et al., 2011).

Many studies have used a cognitive battery before and after receiving training to measure its effect on cognition. This was used to support differential diagnosis between harmonious aging and incipient disease processes by identifying pathological patterns of cognitive changes and to estimate functional capacity (Mattos \& Paixão Júnior, 2010). This study uses the term diagnostic tests for those used both in the delimitation of the sample as for the control of diagnostic and clinical measurements of the sample. It uses the term performance tests for those that are completed pre and post-intervention to assess the likely benefits of the intervention.

It was hypothesized that cognitive training would produce greater gains in cognition and in some specific memory tests. It is also foresaw that the word recovery test could demonstrate the extent to which groups differ and that figures recognition tests and visual memory test reflect the influence of the specific type of training for each group. The Face-Name association test presented greater gain for the group that was submitted to MEMO intervention, as this group used a Face-Name association technique in one of their sessions.

To summarize, this study has the following objectives: 1) Determine whether cognitive intervention results in positive cognitive and memory gain? Assess whether cognitive stimulation and cognitive training produced different effects? 2) Identify the tests (word recognition test, figure recognition test, name-of-face association test or visual memory test) that are more sensitive to the intervention?

\section{Method}

\section{Participants}

The study included finally 44 participants aged between 63 and 77 years old, of both sexes, presenting stable health, cognitively normal and recruited from the local community. The research included the following steps: registration, pre-intervention assessment, intervention, post-intervention assessment and data analysis.

Initially, 87 candidates answered a semi structured interview (Anamnesis) and cognitive tests in order to select those who met the following inclusion criteria: age of 60 years and older; minimum of four years of education; absence of symptoms suggestive of depression - a maximum score of seven points on the 15-item Geriatric Depression Scale (GDS-15) (Almeida \& Almeida, 1999); absence of symptoms suggestive of severe anxiety, with maximum score of 25 points in the Beck Anxiety Inventory - BAI (Beck \& Steer, 1990); and absence of symptoms suggestive of dementia, with a minimum score of 25 points in the Mini-Mental State Examination - MMSE (Bertolucci et al., 1994; Brucki, Nitrini, Caramelli, Bertolucci, \& Okamoto, 2003).

The following conditions resulted in exclusion from the study: visual or hearing deficits; impairment of mobility; being submitted to general anesthesia in up to six months prior to this study; presence or history of psychiatric disorders, neurological diseases and substance abuse.

After applying inclusion and exclusion criteria and considering the sample loss, 53 participants were randomly by blocks design divided in the three intervention groups (two experimental groups and one control group with no intervention). Participants in experimental groups received the MEMO or Stimullus intervention and those in the control group were directed to take part in the intervention that presented best results in the experimental groups after completion of the study for ethical reasons.

Written informed consent was obtained from all candidates. The informed consent form was approved by the CEP/CONEP System (Plataforma Brasil) of an ethical guideline requested by the Brazilian Ministry of Health (No. 11145012.6.0000.5540), according to Brazilian regulations.

Figure 1 describes the starting number of candidates and the sample loss for discontinued intervention due to lack of time or motivation at each stage of the study. 


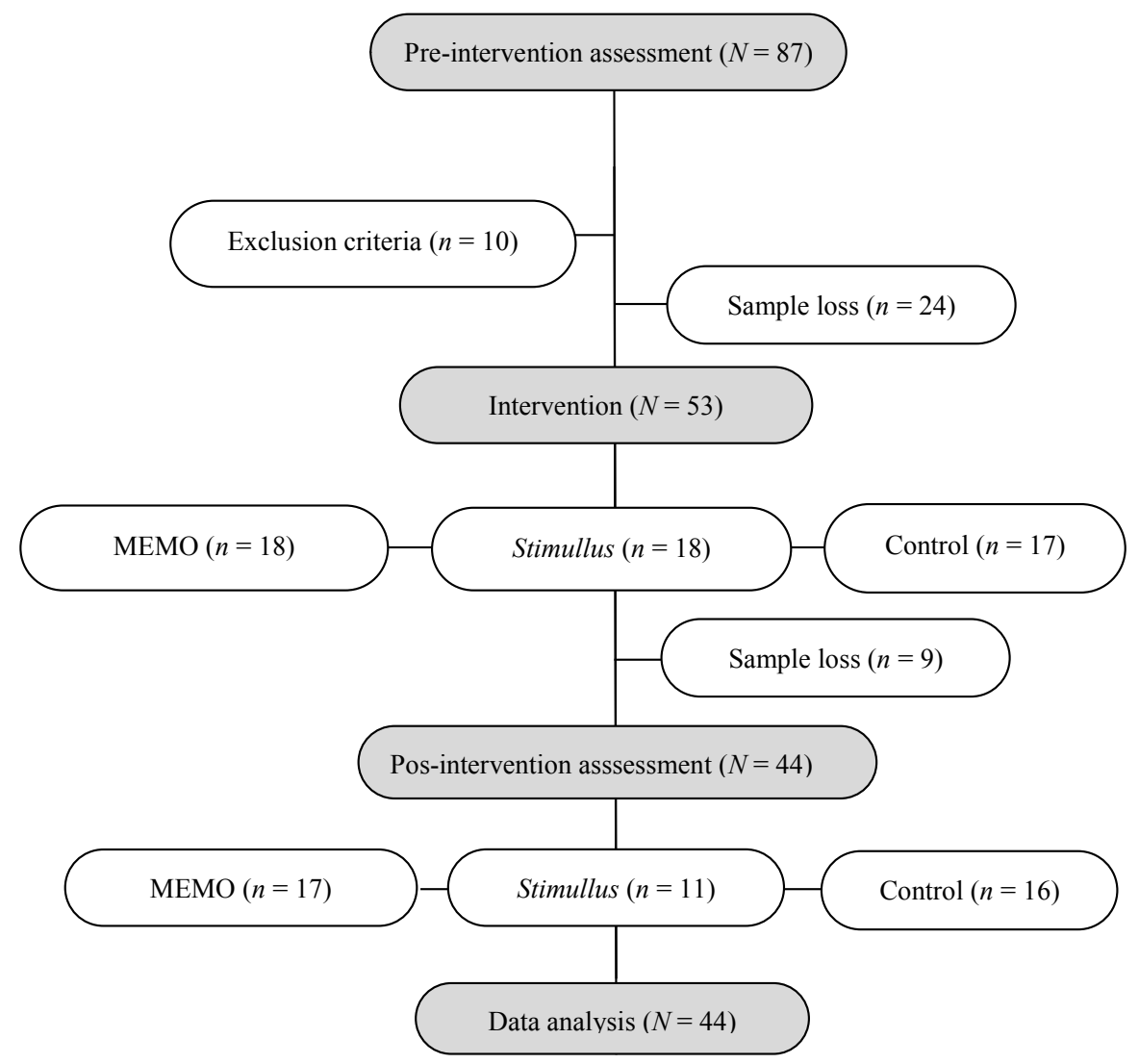

Figure 1. Flow Chart of Study Design.

We expected to obtain statistically comparable groups, according to the chi-square test for categorical variables and the Kruskal-Wallis test for continuous variables. The significance level (p) for statistical tests was $5 \%$.
Table 1 shows the sociodemographic and clinical variables at the pre-intervention moment, regarding the 44 participants who composed the final sample of the study and the statistical significance among the three groups.

Table 1. Sociodemographic and Clinical Variables of Sample at Pre-intervention.

\begin{tabular}{|c|c|c|c|c|}
\hline & & Group & & \\
\hline Variable & MEMO $(n=17)$ & Stimullus $(n=11)$ & Control $(n=16)$ & $p$ \\
\hline Age & $72,0(68,0-74,0)$ & $72,0(63,0-75,5)$ & $69,5(63,0-77,0)$ & $0,95^{a}$ \\
\hline \multicolumn{5}{|l|}{ Sex } \\
\hline Female & $15(82,2 \%)$ & $9(81,8 \%)$ & $12(75,0 \%)$ & \multirow{2}{*}{$0,62^{b}$} \\
\hline Male & $2(11,8 \%)$ & $2(18,2 \%)$ & $4(25,0 \%)$ & \\
\hline \multicolumn{5}{|l|}{ Education } \\
\hline 4 to 8 years of education & $2(11,8 \%)$ & $1(9,1 \%)$ & $2(12,5 \%)$ & \multirow{3}{*}{$0,75^{b}$} \\
\hline 9 to 12 years of education & $5(29,4 \%)$ & $1(9,1 \%)$ & $4(25,0 \%)$ & \\
\hline 13 or more years of education & $10(58,8 \%)$ & $9(81,8 \%)$ & $10(62,5 \%)$ & \\
\hline GDS-15 Score & $3,0(1,0-5,0)$ & $3,0(2,0-3,5)$ & $2,0(1,0-3,0)$ & $0,31^{\circ}$ \\
\hline BAI Score & $5,0(3,0-13,0)$ & $7,0(4,0-12,5)$ & $5,5(2,0-12,3)$ & $0,89^{a}$ \\
\hline MMSE Score & $27,0(27,0-29,0)$ & $29,0(27,0-29,5)$ & $27,5(25,0-28,3)$ & $0,42^{\circ}$ \\
\hline
\end{tabular}

Note. Sex and education represented by their frequencies, with percentages in parentheses. Age and clinical variables represented by their medians, with band interquartile range in parentheses. GDS - Geriatric Depression Scale. BAI - Beck Anxiety Inventory. MMSE - Mini Mental State Examination. ${ }^{a}$ Kruskall-Wallis Test. ${ }^{b}$ Chi-square Test. 
Table 1 indicated that the distribution of participants was statistically similar in all groups, with no significant differences in sociodemographic and clinical variables investigated.

\section{Design}

An experimental design with pre-intervention and post-intervention assessments was applied, using a control group with no intervention. In a mixed factorial design $3 \times 2$, the intervention factor (MEMO, Stimullus and control) was manipulated between subjects and the time of testing factor (pre- and post-intervention) was manipulated within subjects.

The memory performance was evaluated with Image Recognition, Free Recall, Visual Memory and FaceName Association tests. Diagnostic and clinical measures were collected with GDS-15, BAI, MMSE and NEUPSILIN diagnostic tests. Both performance and measures variables were assessed at pre- and post-intervention moments.

\section{Materials}

Materials were classified into four categories: 1 ) diagnostic tests - Anamnesis, MMSE (Bertolucci et al., 1994; Brucki et al., 2003), BAI (Beck \& Steer, 1990), GDS15 (Almeida \& Almeida, 1999) and NEUPSILIN (Fonseca, Salles, \& Parente, 2009); 2) memory tests - Test of Visual Memory - TMV (Pasquali, Veiga, Alves, \& Vasconcelos, 2004), Face-Name-Association test (Vanhalle \& colleagues, 1998), Free Recall test and Image Recognition test; 3) Stimullus cognitive stimulation materials; and 4) MEMO cognitive training materials.

Materials used in TMV consisted of 24 multiple-choice items. Materials used in the Face-Name Association test were adapted for use in Portuguese (Vanhalle \& colleagues, 1998), which is composed by 12 items, and presented in two versions. Materials used in the Free Recall test included 38 selected words by Janczura (1996), having concreteness and frequency of occurrence controlled from written materials. Materials used in the Image Recognition test included 260 pictures from Snodgrass and Vanderwart (1980), half of them presented as targets and half as distractors.

The Stimullus intervention was administered to participants through the following sessions: Visual sequence; Storing of words; Storage of sentences; Categorization of words; Storage of images; and Storage of stories. Materials used in Stimullus sessions were based on adaptations from sessions two to seven of the procedure developed by Chariglione and Janczura (2013). The first session of Chariglione and Janczura's procedure was excluded in order to align the two intervention groups with same number of sessions, frequency and application period.

The MEMO intervention was administered to participants through the following sessions: Information on Memory and Aging; The importance of attention; Mental imagery training; The method of loci; The FaceName association method; and The method PRST. Materials used in MEMO sessions were based on adaptations into Portuguese of the materials presented by Gilbert, Fontaine and Belleville (2011).

\section{Procedures}

Procedures included the following steps: translation and adaptation of MEMO intervention and Face-Name Association test into Portuguese, training of research assistants, pre-intervention, intervention and post-intervention.

Translation and adaptation of MEMO intervention (Gilbert et al., 2011) and Face-Name Association test (Vanhalle \& colleagues, 1998) into Portuguese followed by the five steps proposed by Beaton, Bombardier, Guillemin and Ferraz (2002) for the cross-cultural adaptation of procedures and tools in healthcare: (i) translation (performed by two independent bilingual translators - Portuguese and French), (ii) synthesis (resolution of differences between both translations by a third translator), (iii) back-translation (judgment of the property of the third translator translation from an independent translator, bilingual and original language material), (iv) review (performed by psychologists with expertise in the area of cognitive interventions with older adults) and (v) pre-test and preliminary version (procedure applied in five older adults, to detect difficulties of comprehension and understanding of the procedure and materials). The translation and adaptation of MEMO intervention into Portuguese included the application manual for the administration of the sessions.

The research assistants included a neuropsychologist and six psychology undergraduate students. There was one responsible for their training and that the wizards received adequate training before the beginning of the interventions.

During the pre-intervention diagnostic and memory tests were administered to all 87 candidates, within up to three individual 60 -min sessions, one per week. They were administered within 30 days before the beginning of the intervention procedure. Anamnesis, MMSE, BAI, GDS-15, NEUPSILIN, and TMV were administered orally. Free Recall, Image Recognition and Face-Name Association tests were administered with a computer, using SuperLab 4.0 application (Produced by Cedrus Corporation $^{\oplus}$ ). The oral responses were recorded by

Estudos de Psicologia, 23(1), janeiro a março de 2018, 2-13 
the research assistant on answer sheets and the Image Recognition test responses were stored in the computer.

Each intervention procedure included six sessions distributed in a six-week period, one per week, lasting two hours each. The experimental groups were led by a neuropsychologist, with cognitive intervention experience with older adults, and accompanied by at least two research assistants. In each session of the intervention procedure, the following steps were taken: review of the previous session's content and home exercises, discussion of the week's theme of application, conducting group exercises, recap of the current session's content, and presentation of the exercises to be performed at home. These instructions were standardized for better comparison between experimental groups.

During post-intervention the same pre-intervention tests were administered, except Anamnesis and MMSE. Tests were administered up to 30 days after the conclusion of interventions in three individual $60-\mathrm{min}-$ sessions, one per week. 44 participants completed the post-intervention assessment.

\section{Data Analysis}

The effect of the intervention on memory performance was assessed using the following measures: hits in TMV test; hits discrimination index (memory accuracy measure that indicates the probability that an image is properly recognized) and response bias (probability of a target image to be recognized as a target, when the participant is in doubt if it is target or distractor) in Image Recognition test, calculated according to Snodgrass \& Corwin (1988); amount of retrieved words, in Free Recall test; number of correct associations in Name-Face Association test. The clinical status of the participants was assessed through 16 diagnostic measures: BAI, GDS-15, and 14 NEUPSILIN variables ${ }^{1}$ scores.
The data was first analyzed to assess whether they met the statistical assumptions of parametric analysis normality (Shapiro-Wilk test), homoscedasticity (Levene test), error independence (Durbin-Watson test) and multicollinearity (FIV). Analysis revealed that the data did not meet these assumptions and hence were submitted to nonparametric analysis. The median and interquartile range was considered to evaluate the effects of interventions on memory and diagnostic measures. The intervention type between-groups effect was analyzed by Kruskal-Wallis test with post hoc Mann-Whitney, and the intra-group pre-post effect was analyzed by station signals Wilcoxon test. The significance level was $5 \%(p<0.05)$ for all tests.

\section{Results}

\section{Analysis of the Intervention Effect on Memory Measures}

The intra-group analysis of pre and post intervention performance revealed that participants of the MEMO group showed significant improvement in TMV ( $Z=-2.87, p=0.01, r=-0.43$ ) and, based on their medians, they recognized greater number of images correctly and remained stable in relation to other variables. Participants of the Stimullus group showed significant decline in the probability of correctly recognizing an image $(Z=-2.03$, $p=0.04, r=-0.31)$, improvement in $\operatorname{TMV}(Z=-2,87$, $p=0,01, r=-0,43)$ decline in Face-Name Association test $(Z=-2,03, p=0,04, r=-0,31)$ and remained stable in relation to other variables. Participants of the control group showed improvement in TMV and in the probability of correctly recognizing an image, decline in the number of images correctly recognized and in Face-Name Association test. The remaining variables showed no significant differences as can be observed in Table 2 .

Table 2. Memory Measures in Pre and Post Intervention.

\begin{tabular}{|c|c|c|c|c|}
\hline & & Group & & \\
\hline Varible & $\operatorname{MEMO}(n=17)$ & Stimullus $(n=11)$ & Control $(n=16)$ & $p^{\mathrm{a}}$ \\
\hline \multicolumn{5}{|l|}{ TMV } \\
\hline Post intervantion & $17,00(13,00-19,00)$ & $16,00(15,00-19,00)$ & $16,50(11,75-19,00)$ & 0,87 \\
\hline$p^{\mathrm{b}}$ & 0,01 & 0,32 & 0,22 & \\
\hline Pre intervantion & $209,00(192,00-219,00)$ & $214,00(211,50-218,50)$ & $201,00(186,00-210,25)$ & 0,03 \\
\hline Post intervantion & $214,00(188,00-220,00)$ & $214,00(209,00-216,50)$ & $200,50(182,00-208,25)$ & 0,07 \\
\hline$p^{\mathrm{b}}$ & 0,61 & 1,00 & 0,81 & \\
\hline
\end{tabular}


Cognitive interventions in older adults

Table 2. Continuation

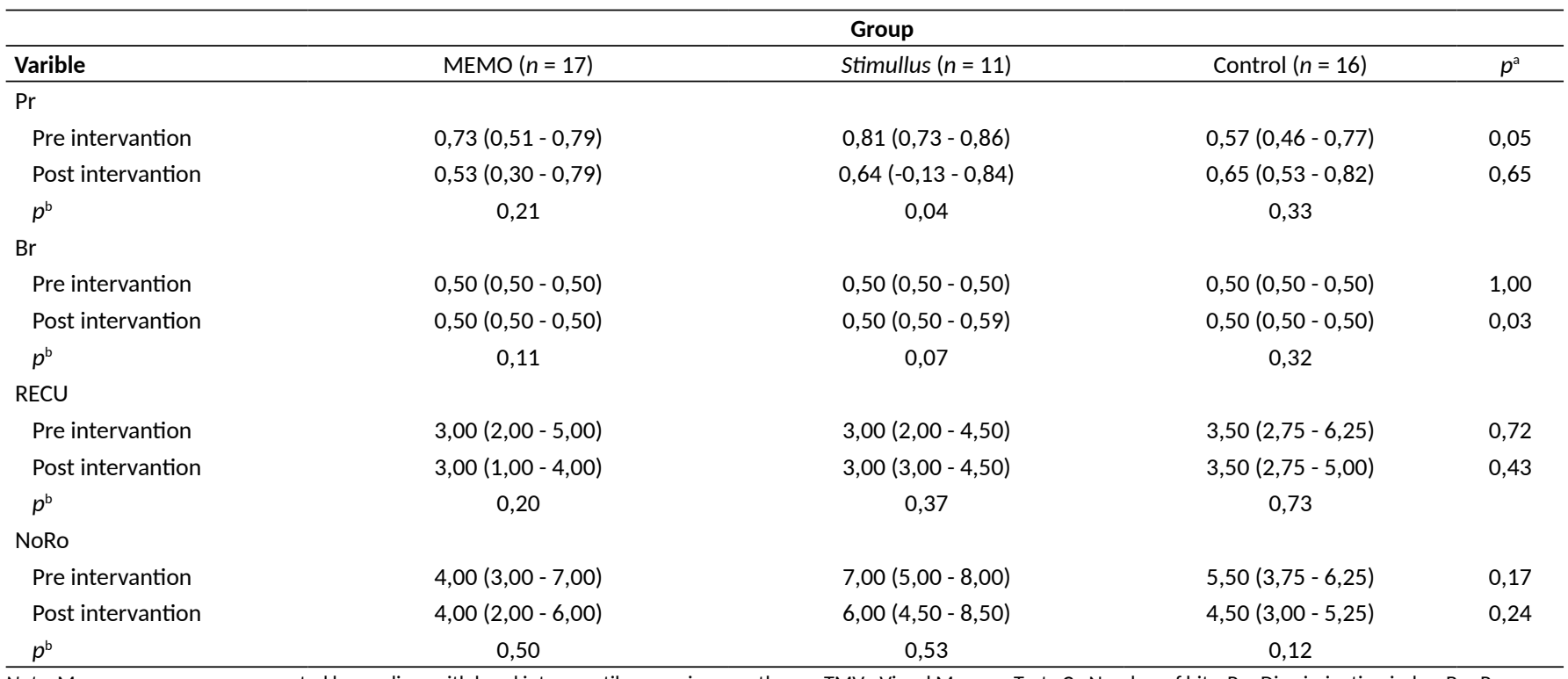

Note. Memory measures represented by median, with band interquartile range in parentheses. TMV - Visual Memory Test. C - Number of hits. Pr - Discrimination index. Br - Response bias. RECU - Word-free recovery test. NoRo - Name-face association. ${ }^{a}$ Kruskall-Wallis Test. ${ }^{b}$ station signals Wilcoxon test.

The between-group analyses indicated significant differences on response bias associated to the Image Recognition test to at post-intervention $(\mathrm{H}(2)=7.22$, $p<0.05)$. Post hoc analysis indicated significant differences between control and MEMO groups $(U=105.00$, $p<0.05, r=-0.30)$ and between control and Stimullus groups $(U=52.50, p<005, r=-0.39)$.

\section{Analysis of Intervention Effect on Diagnostic Measures}

Participants of the Stimullus group showed significant improvement in problem solving $(Z=-2.00$, $p<0.05, r=-0.30$ ). Based on their medians they showed improvement in levels of depression and anxiety, attention, total memory, verbal episodic and semantic memory, but it did not reach significance.

Participants of the MEMO group showed significant improvement in overall memory $(Z=-1.94$, $p<0.05, r=-0.29)$ and verbal episodic semantic memory $(Z=-1.94, p<0.05, r=-0.29)$.

Participants of the control group presented significant improvement in perception cognitive functions $(Z=-2.99$, $p<0.05, r=-0.45)$, short-term visual memory $(Z=-2.12$, $p<005, r=-0.32)$ and verbal fluency $(Z=-2.12, p<0.05$, $r=-0.32$ ). Medians suggest an improvement in levels of anxiety, total memory, working memory, verbal episodic semantic memory, praxis and problem solving, but it did not reach significance as can be observed in Table 3 .

Table 3. Diagnostics Measures in Pre and Post Intervention.

\begin{tabular}{|c|c|c|c|c|}
\hline & & Group & & \\
\hline Variable & $\operatorname{MEMO}(n=17)$ & Stimullus $(n=11)$ & Controle $(n=16)$ & $p^{a}$ \\
\hline \multicolumn{5}{|l|}{ BAI } \\
\hline Post intervantion & $6,00(2,00-10,00)$ & $3,00(2,00-6,50)$ & $3,00(2,00-16,25)$ & 0,66 \\
\hline$p^{\mathrm{b}}$ & 0,26 & 0,12 & 0,93 & \\
\hline \multicolumn{5}{|l|}{ GDS } \\
\hline Post intervantion & $4,00(2,00-5,00)$ & $2,00(1,00-2,50)$ & $2,50(1,75-4,25)$ & 0,16 \\
\hline$p^{\mathrm{b}}$ & 0,52 & 0,10 & 0,74 & \\
\hline \multicolumn{5}{|l|}{ OTE } \\
\hline Pre intervantion & $8,00(8,00-8,00)$ & $8,00(8,00-8,00)$ & $8,00(8,00-8,00)$ & 0,81 \\
\hline Post intervantion & $8,00(7,00-8,00)$ & $8,00(8,00-8,00)$ & $8,00(8,00-8,00)$ & 0,27 \\
\hline
\end{tabular}


Table 3. Continuation

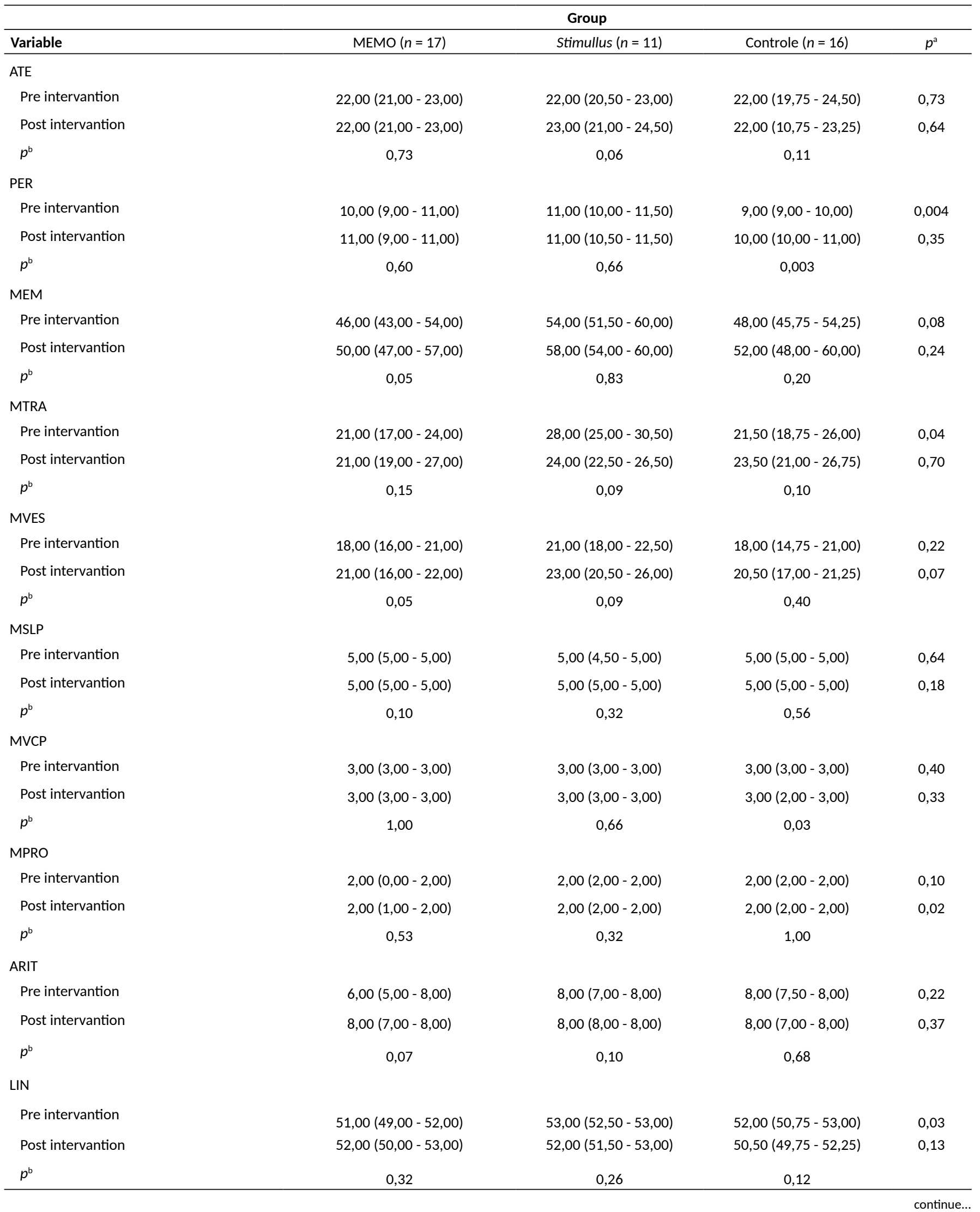


Table 3. Continuation

\begin{tabular}{|c|c|c|c|c|}
\hline & & Group & & \\
\hline Variable & $\operatorname{MEMO}(n=17)$ & Stimullus $(n=11)$ & Controle $(n=16)$ & $p^{\mathrm{a}}$ \\
\hline \multicolumn{5}{|l|}{ PRAX } \\
\hline Post intervantion & $19,00(16,00-20,00)$ & $19,00(18,00-21,00)$ & $18,00(15,75-19,25)$ & 0,47 \\
\hline$p^{\mathrm{b}}$ & 0,77 & 0,66 & 0,41 & \\
\hline Pre intervantion & $2,00(1,00-2,00)$ & $2,00(2,00-2,00)$ & $1,00(1,00-2,00)$ & 0,01 \\
\hline Post intervantion & $2,00(1,00-2,00)$ & $2,00(1,00-2,00)$ & $1,50(1,00-2,00)$ & 0,69 \\
\hline$p^{\mathrm{b}}$ & 0,71 & 0,05 & 0,18 & \\
\hline \multicolumn{5}{|l|}{ FVER } \\
\hline Pre intervantion & $5,00(5,00-7,00)$ & $7,00(5,50-7,50)$ & $5,00(4,75-6,00)$ & 0,05 \\
\hline
\end{tabular}

Regarding the between-group analyses, differences were found on the following variables: perception, working memory, prospective memory, language and problem solving. The group difference was significant for prospective memory $(\mathrm{H}(2)=7.49, p<0.05)$ at postintervention moment. Post hoc analysis detected significant differences between MEMO and Stimullus groups $(U=57.00, p<0.05, r=-0.32)$ and between MEMO and control groups $(U=87.00, p<0.05, r=-0.33)$.

\section{Discussion}

The results of this study in healthy older adults from Brazil indicated positive effects of different cognitive interventions on memory measures and to a lesser degree on some of the measures that are used for diagnostics. The MEMO intervention procedure resulted in more cognitive gains particularly for visual memory, and verbal episodic memory and semantic memory. These results are consistent with previous studies that present cognitive training interventions as a potentially impactful non-pharmacological strategy, with simplified implementation that also promotes social interactions (Belleville et al., 2006; Belleville et al.,2018; Mowszowski et al., 2010; Netto, 2010; Olchik et al., 2012).

Stimullus intervention procedure produced benefits to participants in problem solving, attention, verbal memory and total memory episodic semantics. The participants presented gains in memory and diagnostic measures, compared to the group that underwent cognitive training. These results corroborated Da-Silva et al. (2011) and Dias e Dias de Macedo et al. (2015) in which reports of the families of older adults related positive changes regarding to social and cognitive aspects, inclusively with a positive perception of their performance in the intervention.

Overall and despite a statistically significant effect on some variables, the two experimental groups showed a magnitude of effect of the interventions that was relatively modest relative to the control group as was noted by Belleville et al. (2018), Splinter (2003), Netto (2010), Olchik et al. (2012), Yassuda et al. (2006) and Yassuda et al. (2010). This might be due to the small sample size and/or some variability. Therefore, remains to be conformed with larger groups. This stresses the importance of comparing the change with that of a control group.

Participants in the control group indicated improvement in a few variables, but no significant gain, which may be linked to the fact that the older adults had received attention and had felt included in the study, generating an increase in self-confidence and self-efficacy (Popp \& Schneider, 2015, West \& Thorn, 2001).

The effect of interventions on memory performance was observed in TMV but not on Face-Name Association, Image Recognition and Free Recall tests. Related to the TMV a significant benefit to participants of the MEMO group was observed with minor improvement 
in participants of the Stimullus group. No significant differences were found on the Face-Name Association test, regardless of the type of intervention. This result was unexpected considering that the participants of the MEMO group received specific training on how to perform this kind of association (Belleville et al., 2006).

One hypothesis for the non-significant results of some tests, diagnostics specifically, is related to the sample size per experimental condition. This limitation is also found in other interventions studies many of which rely on small sample size: Belleville et al. (2006), with 47 participants, 28 of which older adults with mild cognitive impairment and 17 healthy older adults; Gagnon and Belleville (2012), with 24 participants, 12 per condition, divided into two groups; Netto (2010), with 20 participants, 11 in an experimental group and nine in the control group; Yassuda et al. (2006), with 69 participants divided into two groups; and Olchik et al. (2012), with 65 healthy older adults and 47 older adults with mild cognitive impairment, divided into four groups).

Difficulty in controlling the effects of retesting is a limitation that was observed in this study and that was also reported by Netto (2010), due to the unavailability of different versions of the same tests, except for the Face-Name Association test. One way to minimize this effect was to randomize the tests in pre- and post-intervention moments. The impact of test repetition could be reduced in further studies by using larger samples as well as assessing the effects of MEMO and Stimullus interventions with longer intervals.

The presented results indicate that more study is need in this area. Continued efforts should be given to improving the training interventions (MEMO and Stimullus) and adapting them to the Brazilian population. Future research should develop programs built on what has already been demonstrated that can improve cognitive performance, aligning scientific knowledge and its applicability to human development. Some training interventions indicated reduction of depressive symptoms, which indicates that subjective gains should also be considered and investigated.

In summary, future studies are expected to respond to demands closer to clinical practice, more interpreted from the neuropsychological point of view, with recommendations for cognitive interventions to patients, documentation of long-term gains from different types of interventions, generalization of gains to other cognitive domains, activities of daily living and improvement of the control group. Despite the variability of the findings, cognitive interventions constitute a fertile field of study in the psychology of aging and can contribute to the maintenance of healthy aging.

\section{References}

Almeida, O. P., \& Almeida, S. A. (1999). Confiabilidade da versão brasileira da Escala de Depressão em Geriatria (GDS) versão reduzida. Arquivos de Neuro-Psiquiatria, 57(2B), 421-426. doi: 10.1590/ S0004-282X1999000300013

Bahar-Fuchs, A., Clare, L., \& Woods, B. (2013). Cognitive training and cognitive rehabilitation for persons with mild to moderate dementia of the Alzheimer's or vascular type: A review. Alzheimers Research and Therapy, 5(4), 1-14. doi: 10.1186\%2Falzrt189

Beaton, D., Bombardier, C., Guillemin, F., \& Ferraz, M. B. (2002). Recommendations for the crosscultural adaptation of health status measure. American Academy of Orthopaedic Surgeons. New York, NY: Institute for Work \& Health.

Beck, A. T., \& Steer, R. A. (1990). Manual for the Beck Anxiety Inventory. San Antonio, TX: Psychological Corporation.

Bellander, M., Eschen, A., Lövdén, M., Martin, M., Bäckman, L., \& Brehmer, Y. (2016). No evidence for improved associative memory performance following process-based associative memory training in older adults. Frontiers in Aging Neuroscience, 8, 326, 1-11. doi: 10.3389\%2Ffnagi.2016.00326

Belleville, S. (2008). Cognitive training for persons with mild cognitive impairment. International Psychogeriatrics, 20(1), 57-66. doi: 10.1017/S104161020700631X

Belleville, S., Clément, F., Mellah, S., Gilbert, B., Fontaine, F., \& Gauthier, S. (2011). Training-related brain plasticity in subjects at risk of developing Alzheimer's disease. Brain, 134(6), 1623-1634. doi: 10.1093/brain/awr037

Belleville, S., Gilbert, B., Fontaine, F., Gagnon, L., Ménard, E., \& Gauthier, S. (2006). Improvement of episodic memory in persons with mild cognitive impairment and healthy older adults: Evidence from a cognitive intervention program. Dementia and Geriatric Cognitive Disorders, 22(5-6), 486-499. doi: 10.1159/000096316

Belleville, S., Hudon, C., Bier, N., Brodeur, C., Gilbert, B., Grenier, S., ... Gauthier, S. (2018). MEMO+: Efficacy, durability and effect of cognitive training \& psychosocial intervention in individuals with mild cognitive impairment. Journal of The American Geriatric Society, 1-9. doi: 10.1111/jgs.15192

Bertolucci, P. H. F., Brucki, S. M. D., Campacci, S. R., \& Juliano, Y. O. (1994). Mini-exame do estado mental em uma população geral: impacto da escolaridade. Arquivos de Neuropsiquiatria, 52, 1-7. doi: 10.1590/S0004-282X1994000100001

Brucki, S. M. D., Nitrini, R., Caramelli, P., Bertolucci, P. H. F., \& Okamoto, I. H. (2003). Sugestões para o uso do Mini-Exame do Estado Mental no Brasil. Arquivos de Neuropsiquiatria, 61(3-B), 777-781. doi: 10.1590/S0004-282X2003000500014

Butler, M., McCreedy, E., Nelson, V. A., Desai, P., Ratner, E., Fink, ... Kane, R. L. (2018). Does cognitive training prevent cognitive decline?: A systematic review. Annals of Internal Medicine, 168, 63-68. doi: 10.7326/M17-1531

Chariglione, I. P. F., \& Janczura, G. A. (2013). Contribuições de um treino cognitivo para a memória de idosos institucionalizados. Psico-USF, 18(1), 13-22. doi: 10.1590/S1413-82712013000100003 
Cognitive interventions in older adults

Clare, L., Wilson, B. A., Carter, G., Breen, K., Gosses, A., \& Hodges, J. R. (2000). Intervening with everyday memory problems in dementia of Alzheimer type: An errorless learning approach. Journal of Clinical and Experimental Neuropsychology, 22(1), 46-132. doi: 10.1076/1380-3395(200002)22:1;1-8;FT132

Clare, L., Woods, R. T., Moniz Cook, E. D., Orrell, M., \& Spector, A. (2003). Cognitive rehabilitation and cognitive training for early-stage Alzheimer's disease and vascular dementia (Cochrane Review). The Cochrane Library (Issue 4). doi: 10.1002/14651858.CD003260

Clare, L., van Paasschen, J., Evans, S. J., Parkinson, C., Woods, R. T., \& Linden, D. E. J. (2009). Goal-oriented cognitive rehabilitation for an individual with mild cognitive impairment: Behavioural and neuroimaging outcomes. Neurocase, 15(4), 1-14. doi: $10.1080 / 13554790902783116$

Da-Silva, S. L., Pereira, D. A., Veloso, F., Satler, C. E., Arantes, A., \& Guimarães, R. M. (2011). Programa de reabilitação neuropsicológica da memória aplicada à demência: um estudo não controlado intra-sujeitos. Estudos de Psicologia, 28(2), 229-240. doi: 10.1590/S0103-166X2011000200010

Dias E Dias de Macedo, L., De Oliveira, T. C. G., Soares, F. C., BentoTorres, J., Bento-Torres, N. V. O., Anthony, D. C., \& Picanço-Diniz, C. W. (2015). Beneficial effects of multisensory and cognitive stimulation in institutionalized elderly: 12-months follow-up. Clinical Interventions in Aging, 10, 1351-1360. doi: 10.2147/CIA.S80997

Fernandes, B. L. V. (2014). Atividade física no processo de envelhecimento. Revista Portal de Divulgação, 40, 43-48. Retrieved from https://www.portaldoenvelhecimento.com/revista-nova/index.php/ revistaportal/article/view/443/443

Fonseca, R. P., Salles, J. F., \& Parente, M. A. M. P. (2009). Instrumento de Avaliação Neuropsicológica Breve Neupsilin. Porto Alegre: Vetor.

Gagnon, L. G., \& Belleville, S. (2012). Training of attentional control in mild cognitive impairment with executive deficits: Results from a double-blind randomized controlled study. Neuropsychological Rehabilitation, 22(6), 809-825. doi: 10.1080/09602011.2012.691044

Gilbert, B., Fontaine, F. S., \& Belleville, S. (2011). Programme MEMO - méthode d'entraînement pou r une mémoire optimal. Guide à l'intention des animateurs.

Gross, A. L., Rebok, G. W. Unverzagt, S. L., \& Brandt, J. (2011). Word list memory predicts everyday function and problem-solving in the older adults: Results from the ACTIVE cognitive intervention trial. Aging, Neuropsychology and Cognition, 18(2), 129-146. doi: 10.1080\%2F13825585.2010.516814

Instituto Brasileiro de Geografia e Estatística (2014). População brasileira deve chegar ao máximo (228,4 milhões) em 2042. Retrieved from http://saladeimprensa.ibge.gov.br/noticias?view=n oticia\&id=1\&busca $=1$ \&idnoticia $=2455$.

Janczura, G. A. (1996). Normas associativas para 69 categorias semânticas. Psicologia: Teoria e Pesquisa, 12(3), 237-244.

Lasca, V. B. (2003). Treinamento de memória no envelhecimento normal. (Master's dissertation). Retrieved from http://repositorio.unicamp.br/jspui/handle/REPOSIP/252308

Mattos, P., \& Paixão Júnior, C. M. (2010). Envelhecimento e comprometimento cognitivo leve. In Malloy-Diniz e cols. (Eds.), Avaliação Neuropsicológica. (pp. 247-253). Porto Alegre: Artmed.

Moraes, E. N., Moraes, F. L., \& Lima, S. P. (2010). Características biológicas e psicológicas do envelhecimento. Revista Médica de Minas Gerais, 20(1), 67-73. Retrieved from http://www.rmmg.org/ Sumario/34
Mowszowski, L., Batchelor, J., \& Naismith, S. L. (2010). Early intervention for cognitive decline: Can cognitive training be used as a selective preventive technique? International Psychogeriatrics, 22(4), 537-548. doi: $10.1017 / S 1041610209991748$

Naveh-Benjamin, M., \& Mayr, U. (2018). Age-related differences in associative memory: Empirical evidence and theoretical perspectives. Psychology and Aging, 33(1), 1-6. doi: 10.1037/pag0000235

Netto, T. M. (2010). Treinamento cognitivo da memória de trabalho em adultos idosos. (Doctoral dissertation). doi: 10.1590/ S0103-56652010000200021

Olchik, M. R., Mattos, D., Maineri, N. S., Farina, J., Oliveira, A., \& Yassuda, M. S. (2012). Revisão: efeitos do treino de memória em idosos normais e em idosos com comprometimento cognitivo leve. Temas em Psicologia, 20(1), 235-245. Retrieved from http://pepsic. bvsalud.org/scielo.php?script=sci_arttext\&pid=S1413-389X20120 00100017\&lng=pt\&tlng=pt

Pasquali, L., Veiga, H., Alves, S., \& Vasconcelos, T. (2004). Teste de Memória Visual (TMV). Brasília: LabPam.

Popp, L., \& Schneider, S. (2015). Attention placebo control in randomized controlled trials of psychosocial interventions: Theory and practice. Trials, 16, 150-153. doi: 10.1186\%2Fs13063-015-0679-0

Santos, M. T., \& Flores-Mendoza, C. (2017). Treino cognitivo para idosos: uma revisão sistemática dos estudos nacionais. Psico-USF, 22(2), 337-349. doi: 10.1590/1413-82712017220212

Snodgrass, J. G., \& Corwin, J. (1988). Pragmatics of measuring recognition memory: applications to dementia and amnesia. Journal of Experimental Psychology: General, 117, 34-50. doi: 10.1037/0096-3445.117.1.34

Snodgrass, J. G., \& Vanderwart, M. (1980). A standardized set of 260 pictures: Norms for name agreement, image agreement, familiarity, and visual complexity. Journal of Experimental Psychology: Human, Learning and Memory, 6(2), 174-215. doi: 10.1037/0278-7393.6.2.174

Vanhalle, C., van der Linden, M., Belleville, S., \& Gilbert, B. (1998). Cognitive intervention case studies: Putting names on faces: use of a spaced-retrieval strategy in a patient with dementia of the Alzheimer type. Perspectives on Neurophysiology Neurogenic Speech Language Disorders, 8(8), 17-21. doi: 10.1044/ nnsld8.4.17

West, R. L., \& Thorn, R. M. (2001). Goal-setting, self-efficacy, and memory performance in older and younger adults. Experimental Aging Research, 27, 41-65. doi: 10.1080/03610730126109

Xavier, F. (2006). O transtorno cognitivo da depressão geriátrica ou a "pseudodemência depressiva" do idoso. In M. A. M. P. Parente (Ed.), Cognição e Envelhecimento (pp. 205-224), Porto Alegre, Brasil: Artmed.

Yassuda, M. S., Batistoni, S. S. T., Fortes, A. G., \& Neri, A. L. (2006). Treino de memória no idoso saudável: benefícios e mecanismos. Psicologia Reflexão e Crítica, 19(3), 470-481. doi: 10.1590/ S0102-79722006000300016

Yassuda, M. S., Flaks, M. K., Pereira, F. S., \& Forlenza, O. V. (2010). Avaliação neuropsicológica de idosos - demências. In Malloy-Diniz e cols (Eds.), Avaliação Neuropsicológica. (pp. 254-271). Porto Alegre: Artmed.

Yassuda, M. S., \& Paulo, D. L. V. (2010). Queixas de memória de idosos e sua relação com escolaridade, desempenho cognitivo e sintomas de depressão e ansiedade. Revista de Psiquiatria Clínica, 37(1), 23-26. doi:10.1590/S0101-60832010000100005 
1. NEUPSILIN variables: OTE - Orientation temporospatial, ATE - Attention, PER - Perception, MEM - Memory, MTRA - Working Memory, MVES - Verbal Memory Episode Semantics, MSLP - Semantic Memory Long Term, MVCP - Visual Short-Term Memory, MPRO - Prospective memory, ARIT - Arithmetic, LIN - Language, PRAX - praxis, RES - solving problems, FEVR - Verbal Fluency.

Isabelle Patriciá Freitas Soares Chariglione, Doutora em Cognição e Neurociências, Universidade de Brasília (UnB), é Professora Doutora da Universidade Católica de Brasília (UCB). Endereço para correspondência: Universidade Católica de Brasília, Curso de Pós-Graduação Stricto Sensu em Gerontologia, QS 7, LT 01, Sala S-09 - Águas Claras, Brasília - DF, Brasil. CEP: 71966-700. Telefone: +55(61) 3356 9611. E-mail: isabelle.chariglione@ucb.br

Gerson Américo Janczura, Doutor em Psicologia Cognitiva Experimental pela University of South Florida (USF), é Professor colaborador da Universidade de Brasília (UnB). E-mail: janczura@unb.br

Sylvie Belleville, Pós-Doutora em Neuropsicologia Clínica pela Université de Montreal (UdeM), é Professora Titular da Université de Montreal (UdeM). E-mail: sylvie.belleville@umontreal.ca

Received in 24.Fev.16 Revised in 02.Abr.18

Accepted in 13.Jun.18 